\title{
A Ming Chronology
}

THE EARLY MING (I368-I450)

I368 Zhu Yuanzhang founds the Ming dynasty and enthrones himself as the Hongwu emperor; orders every county magistrate to set up four granaries; cancels the book tax

I369 Hongwu orders every county magistrate to open a Confucian school

I380 Hongwu purges Chancellor $\mathrm{Hu}$ Weiyong and imposes direct imperial rule

I38I the lijia village registration system is universally imposed

I 398 death of the Hongwu emperor

I400 date of the earliest surviving land-sale contract in the Ming

I402 Zhu Di ascends the throne after overthrowing his nephew, the Jianwen emperor, and declares the inauguration of the Yongle reign the following year

I405 Zheng $\mathrm{He}$ launches the first of his six expeditions into the waters around Southeast and South Asia

I4I 5 the Grand Canal is fully restored to use

I420 the Yongle emperor confers the name Beijing on his new capital

I429 a series of seven customs barriers is installed along the Grand Canal 
I433 the seventh and last of the great maritime expeditions reaches Africa; cotton appears as a permanent item on the tax registers in Songjiang prefecture

I436 a portion of the southern grain tax is commuted to silver; inauguration of the reign of the Zhengtong emperor

I449 the rebellion of Deng Maoqi's "silver bandits" in Fujian is suppressed; Beijing officials depose the Zhengtong emperor after he is captured by the Mongols in favor of his brother, who ascends as the Jingtai emperor in 1450

THE MID-MING (I450-I550)

I457 restoration of the Zhengtong emperor as the Tianshun emperor

I464 marginal people in the hills of the interior province of Huguang rebel

I465 massive flooding in central and south China sets off a spate of bridge building

I492 the commercial transportation of grain to the northern border in exchange for salt certificates is monetarized

I 506-2I troubled reign of the Zhengde emperor

I 506 the local costs of the courier system are met by a tax in silver assessed on landholdings rather than by corvée

I 525 Ministry of War orders ships of more than one mast on the southeast coast seized, investigated, and destroyed

I527 granary quotas are severely reduced, diminishing the state's capacity to relieve famines

I 538 first in a decade-long wave of severe famines and epidemics sweeps central and southeast China

I 548 closure of the coast against all foreign trade

I549 Portuguese and Chinese begin regular seasonal trading at Sao João Island near Macao

THE LATE MING (1550-1644)

I 557

Portuguese gain permission to establish a permanent settlement on the Macao peninsula (retroceded in 1999) 
I567 the ban is lifted on maritime trade to all but Japan

I570 the first commercial route book is published in Suzhou

I573-I620 reign of the Wanli emperor

I 58I Chief Grand Secretary Zhang Juzheng imposes the Single Whip Reform, by which taxes are assessed on land and paid in silver

I582 earliest reference to the publishing of private newssheets in Beijing

I 587 severe nationwide famine

1602 the iconoclastic Confucian philosopher Li Zhi commits suicide in prison

I629 the Chongzhen emperor reiterates the state prohibition against female infanticide; a third of courier stations are closed for lack of funds the Beijing Gazette switches to movable type massive epidemic throughout north and central China 1642 Manchus raid into Shandong province rebels capture Beijing and the Chongzhen emperor commits suicide; the Manchus invade and declare the founding of the Qing dynasty 
